\title{
Economic growth, innovation systems, and institutional change : a trilogy in five parts
}

Citation for published version (APA):

Parto, S., Ciarli, T., \& Arora, S. (2005). Economic growth, innovation systems, and institutional change : a trilogy in five parts. MERIT, Maastricht Economic Research Institute on Innovation and Technology. MERIT-Infonomics Research Memorandum Series No. 021 https://doi.org/10.26481/umamer.2005021

Document status and date:

Published: 01/01/2005

DOI:

10.26481/umamer.2005021

Document Version:

Publisher's PDF, also known as Version of record

\section{Please check the document version of this publication:}

- A submitted manuscript is the version of the article upon submission and before peer-review. There can be important differences between the submitted version and the official published version of record.

People interested in the research are advised to contact the author for the final version of the publication, or visit the DOI to the publisher's website.

- The final author version and the galley proof are versions of the publication after peer review.

- The final published version features the final layout of the paper including the volume, issue and page numbers.

Link to publication

\footnotetext{
General rights rights.

- You may freely distribute the URL identifying the publication in the public portal. please follow below link for the End User Agreement:

www.umlib.nl/taverne-license

Take down policy

If you believe that this document breaches copyright please contact us at:

repository@maastrichtuniversity.nl

providing details and we will investigate your claim.
}

Copyright and moral rights for the publications made accessible in the public portal are retained by the authors and/or other copyright owners and it is a condition of accessing publications that users recognise and abide by the legal requirements associated with these

- Users may download and print one copy of any publication from the public portal for the purpose of private study or research.

- You may not further distribute the material or use it for any profit-making activity or commercial gain

If the publication is distributed under the terms of Article $25 \mathrm{fa}$ of the Dutch Copyright Act, indicated by the "Taverne" license above, 


\section{MERIT-Infonomics Research Memorandum series}

Economic growth, innovation systems, and institutional change: A Trilogy in Five Parts

Saeed Parto, Tommaso Ciarli \& Saurabh Arora 2005-021

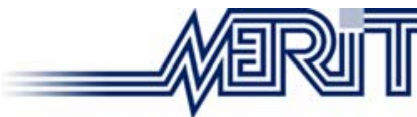

MERIT - Maastricht Economic Research Institute on Innovation and Technology

PO Box 616

6200 MD Maastricht

The Netherlands

T: +31433883875

F: +31433884905

http://www.merit.unimaas.nl e-mail:secr-merit@merit.unimaas.nl

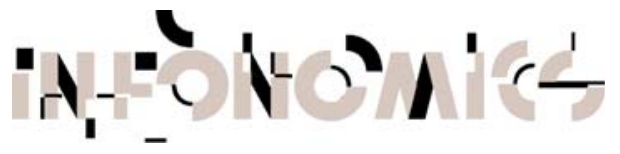

International Institute of Infonomics

c/o Maastricht University PO Box 616

6200 MD Maastricht

The Netherlands

T: +31433883875

F: +31453884905

http://www.infonomics.nl e-mail: secr@infonomics.nl 


\title{
Economic growth, innovation systems, and institutional change: "A Trilogy in Five Parts"
}

\author{
Saeed Parto ${ }^{1}$ \\ Tommaso Ciarli ${ }^{2}$ \\ Saurabh Arora $^{3}$
}

\begin{abstract}
Development and growth are products of the interplay and interaction among heterogeneous actors operating in specific institutional settings. There is a much alluded-to, but under-investigated, link between economic growth, innovation systems, and institutions.

There is widespread agreement among most economists on the positive reinforcing link between innovation and growth. However, the importance of institutions as catalysts in this link has not been adequately examined. The concept of innovation systems has the potential to fill this gap. But these studies have not conducted in-depth institutional analyses or focussed on institutional transformation processes, thereby failing to link growth theory to the substantive institutional tradition in economics. In this paper we draw attention to the main shortcomings of orthodox and heterodox growth theories, some of which have been addressed by the more descriptive literature on innovation systems. Critical overviews of the literatures on growth and innovation systems are used as a foundation to propose a new perspective on the role of institutions and a framework for conducting institutional analysis using a multi-dimensional typology of institutions. The framework is then applied to cases of Taiwan and South Korea to highlight the instrumental role played by institutions in facilitating and curtailing economic development and growth.
\end{abstract}

\subsection{Introduction}

The reliance in mainstream economics on formal, model-based argumentation led Wassily Leontief in 1971 to state: "uncritical enthusiasm for mathematical formulation... [in economics means that] anyone capable of learning elementary, or preferably advanced calculus and algebra, and acquiring acquaintance with the specialized terminology of economics can set himself up as a theorist" (quoted in Smelser and Swedberg 1994:7). While Leontief's statement may hold true for a large portion of scholarly output in economic theory, neither we, and we think, nor Leontief and most other critics of mainstream economics are of the opinion that there is no value in economic theorising using a formal tool-kit. It is our premise, however, that there is a great potential and need for bridging the gap between formal economic analysis and the more contextual details of economic activity that require qualitative analysis. We see an opportunity to realize this potential given the proliferation over the last

\footnotetext{
$\nabla$ Dedicated to Douglas Adams' grasp of arithmetic. We thank Giulia Felice for valuable comments on an earlier draft. The usual disclaimers apply.

${ }^{1}$ MERIT, Keizer Kareplein 19, 6211 TC Maastricht, The Netherlands. E-mail: s.parto@MERIT.unimaas.nl

${ }^{2}$ University of Birmingham. This paper was largely written during Tommaso Ciarli's stay at MERIT as a Marie Curie Fellow in 2004. t.ciarli@gmail.com

${ }^{3}$ UNU-INTECH, Keizer Kareplein 19, 6211 TC, Maastricht, The Netherlands. arora@intech.unu.edu
} 
two decades of writings in evolutionary economics and innovation systems: the embedded nature of economic activity, and the emphasis on the role of "institutions" in these literatures. In this paper we aim to provide a set of interpretive tools that allow a more context-specific understanding of the processes underlying industrial development and growth.

The notion of growth as employed in traditional neo-classical economics focuses largely on changes in GDP without paying adequate attention to structural changes manifest in the continuous (re)organization of the economic system. Such an approach provides little insights into the causal relations that drive the development and growth processes. Economic historians, relying on detailed narratives, are generally more successful in capturing these causal relations than economists working with sophisticated mathematical tools to analyze quantifiable observations of complex socioeconomic phenomena. Although some mainstream economists have relied on "stylised facts"4 to justify the assumptions of their growth models, the empirical implications of narrative-based approaches are, in our view, more significant: A narrative-based approach can capture the substantial deviations in the development process and in the object of analysis, i.e., a national economy. Economic historians explain qualitative change and development in a "localized" context to highlight such context-specific features as formal and informal institutions, socio-cultural idiosyncrasies, creation/diffusion of technological knowledge, and the structural landscape. If growth is that idealization of economic dynamics in which things simply get bigger or smaller or stay the same size (Dosi et al. 1994), growth models are merely the final representations of these changes and thus inadequate to account for the range of dynamic processes that underlie industrial development.

This is by no means a novel observation. The link between development and growth has been the subject of analysis for scholars of structural change, regulation theory, institutional economics, and innovation systems. There is also a small but significant body of work on social capital that combines elements from history, sociology, economic geography, politics, and anthropology to account for the unevenness of development and growth globally. ${ }^{5}$ The shared premise of these alternate approaches is that growth should not, and cannot, be analysed from an aggregate perspective alone. As Wood (1994:66) argues, relatively rapid micro structural changes precede the slower macro developments. Growth is not the sum total of factors that drive development but the interactions between "conditions" and "elements" that co-evolve to generate growth. The elements represent the micro (and part meso) dimension while the conditions are the macro (and part meso) variables.

In other words, one needs to understand the micro-underpinnings of the macro variables and their interaction with one another in specific socio-cultural and political contexts to fully account for growth. In a similar vein, von Tunzelmann (1995:16) states, "to understand industrialization thus requires a multi-dimensional approach: the process of industrialisation cannot be collapsed into a single dimension, as is done in orthodox economics." If, for example, at the aggregate level growth can be expressed through a

\footnotetext{
4 The notion of "stylised facts" was apparently first introduced by Kaldor during the Conference of the International Economic Association in Corfu in 1958. He suggested the use of stylised facts to refer to phenomena which have been observed in a vast number of circumstances and thus deserve being explained or tested as hypotheses.

5 See, for example, Jacobs (1961), Bourdieu (1983), Coleman (1988), and Putnam (1993, 1995, 2000).
} 
production function, in which two or three elements appear, one cannot do away with an explanation of the dynamics that lead to changes in the elements of the production function if one is concerned with an understanding of growth processes. To accomplish this task effectively, one must depart from "aggregate growth" as the primary object of analysis to examine the interactions between the different factors of production in a given context. This perspective is all the more important if one seeks to understand the development processes that lead to growth.

The link between development and growth can be understood through an investigation of the interconnected "deepest causes" of development together with the "proximate sources” of growth (Abramovitz 1989). ${ }^{6}$ Any in-depth examination along these lines requires a disaggregation of the growth process without assuming representative agents and their return on capital with homogeneous output; or the assumed dynamics of technological progress stemming from increasing returns, non-competitive markets and spillover effects. Such assumptions of homogeneity eliminate the possibility of explaining the trap of underdevelopment, or the "miracle" of rapid development by newly industrialized countries such as Taiwan and South Korea.

Developed and newly industrialized economies have undergone multiple processes of industrial and institutional transformation. As Kuznets (1966) observed, the start of a new economic epoch after the industrial revolution signalled the emergence of a fundamentally different structure in the world system of production and consumption. As a result, significant changes took place in the sectoral composition of industrializing economies, relations among countries, and in the alignment of advances in science and technology. This process went hand in hand with changes in national institutional arrangements. Examples of institutional transformation include the establishment of credit markets, (intellectual) property rights' regimes, human rights and well-being standards, citizens' involvement, and a proliferation of private and public networks expressive of a diverse set of interests and, most importantly, government intervention. ${ }^{7}$

In traditional neo-classical growth theory technical change is "simply" modelled with a shift in the production function that represents the adoption of a more productive technology. But as Ayres (1962:125-54) argued, “technology is essentially an autonomous, self-sustaining process,... the potential for fruitful discoveries will be enhanced in a receptive environment" (cited in Street [1987:1883]). In a similar vein, Fagerberg and Verspagen (2002:2) note, "technological catch-up is not a question of replacing an outdated technological set up with a new one, but to continually transform technological, economic and institutional structures." In order to understand why this continual transformation does not occur in countries where it is most needed, one must construct narratives of the political

\footnotetext{
${ }^{6}$ Abramovitz's proximate sources of growth include technological change, economies of scale, human and tangible capital accumulation (Abramovitz 1993).

${ }^{7}$ There is an extensive stream of literature in mainstream growth theory from the last decade that uses institutions as a link between income distribution and economic growth. For a general overview of this literature, see Benabou (1996). These studies have investigated the relationship of growth to educational systems (human capital) (see for example, Glomm and Ravikumar 1992) and credit market imperfections (Galor and Zeira 1993); and to voting mechanisms or political stability/conflict (see Persson and Tabellini 1994; Perotti 1993). As the bulk of this literature does not focus on industrial/technological change, a review is out of the scope of this paper.
} 
economy which combine historical descriptions with a re-articulation of stylised facts to simultaneously grasp the "how's" and the "why's": the creation and diffusion of new technologies depends on pre-existing milieus (Street 1987). As we will show later, the advancements made by Taiwan and South Korea toward becoming newly industrialized economies have been firmly embedded in pre-existing milieus, or the integrated webs of formal and informal institutions, which served as the foundation for policy and planning for socio-economic transformation. In countries where appropriate pre-existing milieus are not present they can be "engineered" (Putnam 1993), through capability-enhancing national and international measures including favourable terms of trade, appropriate property rights regimes, and development aid, ${ }^{8}$ all of which seem to have played key roles in the development of Taiwan and South Korea.

This paper is structured as follows. In section 2, we provide a critical overview of prominent growth models in the orthodox tradition of economics, and in two heterodox traditions, namely evolutionary economics and the structuralist/Kaldorian approaches. In Section 3, we provide a synthesis of the more descriptive, and more encompassing, literature on innovation systems. Here we discuss how the oft-neglected analysis of the transformation of innovation systems is necessary from the perspective of developing economies. In section 4, we present a methodology for analysing institutions and the institutional context in studies of development and growth. We briefly discuss how this methodology may be applied using examples from the history of economic development in South Korea and Taiwan. We conclude in section 5 and explore future directions for research on the development process in a context-rich and institutionally sensitive manner.

\subsection{Growth Theorising}

Economists have traditionally focused on formalizing growth processes where the "expansion" of aggregate GDP is related to the expansion of aggregate inputs, which are influenced by other variables that determine both input expansion and their impact on growth. Most growth models possess these 'mechanisms' of relating 'inputs' to 'outputs' using simplified causal relations, and therefore have an appeal to the policy maker who prefers things in a 'nutshell'. Over the last two decades, however, different ways for treating economic growth in formalized terms have emerged. These approaches differ from traditional growth theory in their choice of assumptions, levels of aggregation, the relevant mechanisms studied, and mathematical representation. This large range of approaches has brought us to the point where, as stated by Wood (1994), each of us already has a basic model which serves as a background for any analysis. However, many models are not extended to take into account, or not be in contradiction with, the stylised facts presented by the history of economic development and growth. ${ }^{10}$

\footnotetext{
${ }^{8}$ Here we are referring to scientific, technological, and organizational capabilities that underlie technological development. These capabilities manifest at social (individual), organizational, and societal levels (see section 5.1 below for more details on these levels).

9 'Expansion' is used by Wood (1994) in contraposition to 'change'.

${ }^{10}$ For a specific example, see Jones (1995) who points out that the "scale effects" prediction of most R\&Dbased growth models finds little empirical support.
} 
In this section, we first review the orthodox approaches to growth and some of the improvements made by the New Growth Theory (NGT), which although important remain "technical in nature" (Aghion and Howitt 1994:118). We then link some fundamental critiques of the orthodox models with main elements of heterodox approaches that attempt, in various ways, to open the black box of aggregate entities and analyse some of the underlying mechanisms (e.g. heterogeneous economic agents, endogenous technological innovation, non-homogenous demand, cumulative processes, and the like). Through these brief reviews we aim to underline the need to account for the role of institutions, which constitute the environment in which the disaggregated elements interact and (co-)evolve.

\subsection{Orthodox Growth Models: a fallacious endogenisation of technical change and consumption?}

Most mainstream growth models, until the emergence of the New Growth Theories, have been macroeconomic models within a 'dynamic general equilibrium' framework. That is, at any point in time, all variables are assumed to adjust to values which maintain the system in a state where demand and supply sides match: no market adjustment process is considered other than immediate changes in prices. The functional relation between the determinants of growth and their result, at the aggregate level, is presented in the form of an aggregate CobbDouglas production function: ${ }^{11}$ each country produces one homogenous output with two homogenous inputs, labour and capital. ${ }^{12}$ This representation was first articulated in the Solow-Swan model (Solow 1956; 1957; Swan 1956). The Cobb-Douglas function has wellknown limitations in its underlying assumptions (see for example Robinson 1953 and Pasinetti 1966). ${ }^{13}$ Second, the Solow-Swan model relies on the experiences of industrialised countries, and has little relevance for less developed economies. ${ }^{14}$ Third, there is no explanation of a main driver of growth: technical change. ${ }^{15}$ Fourth, empirical evidence of long-run convergence among countries with different initial levels of GDP, as suggested by the Solow-Swan model, has not been found (Lucas 1988, Romer 1986). Convergence is only conceivable in a world where technological change is exogenous and available to all countries:

\footnotetext{
11 In contrast, the post-Keynesian Harrod-Domar model (Domar 1946, Harrod 1949) is represented using a Leontief fixed coefficients function.

12 The only difference in output allowed is in quantity, but never in quality. That is, the technological factor introduced by Solow allows for shifts in the linear production function in the form of process changes only. 13 To name a few, perfect substitution between production factors, decreasing returns to scale, perfect reversibility of inputs, knowledge as a public good, perfect competitiveness of markets, price-based interactions, perfect information, and validity of Say's law. Further, drawing from Sylos (2000), the fallacies of using the Cobb-Douglas function include, i) defining a monotonic relation between rate of profits and capital per capita (Pasinetti 1966); ii) given prices; iii) firms being in a position to minimise costs; iv) all capital goods readily aggregable and substitutable; v) ready availability of all production techniques and their combinations. Finally, no difference is postulated between 'available process frontier' and 'fundamental production frontier' (David 1975). 14 See, for example, Coombs (1987) and Easterly (2002).

${ }^{15}$ Solow (1994b) argues that exogenous technical change is not a serious drawback and endogenising it is not so useful as it does not really add to our understanding of growth, at least not in the way it is endogenised by the New Growth Theory: "The new-growth-theory treatment of endogenous technical progress is pretty crude, it certainly does not come close to describe what happens in economic research and there is no reason to suppose it is much better on technological research. There are scholars who look closely at what goes on in industrial
} 
Neither of these two assumptions allows for an explanation of the observed divergent growth rates (Romer 1994). Fifth, how can growth be sustained if its main determinants are exogenous? If both population growth and technical change are considered exogenous, there can actually be no role for policy intervention (Arrow 1962; Romer 1989).

Some drawbacks of the traditional orthodox growth theory have been addressed by the proponents of the NGT. Their main contribution has been to introduce different mechanisms of endogenous increase in the technological factor and drop the assumption of diminishing returns to investment at the aggregate level. Thus, markets can be non-strictly competitive, and the radical marginalist assumption that all the production factors are paid through their marginal private productivity is abandoned. In addition, a certain degree of disaggregation is introduced to account for the behaviour of firms (in R\&D growth models such as Romer 1990; Aghion and Howitt 1992); and consumers in allocation of resources, thereby endogenising the rates of investment and saving. Nonetheless, the basic assumptions of perfect rationality, homogeneity of consumers (Ramsey (1928) type inter-temporal consumption), and the use of a representative agent cast doubts on the contribution of NGT in understanding growth and development.

The different NGT models may be broadly classified according to the primary mechanisms they use to explain endogenous growth. Amable and Guellec (1992) distinguish between four broad categories of growth models: i) investment in capital, accumulating at a national level though externalities (Romer 1986); ii) public goods, also in terms of investment at the aggregate economy level (Barro 1990); iii) accumulation of buman capital (Lucas 1988); and iv) technological innovation as a systematic activity - often manifest as R\&D - introduced in different forms by Romer (1990), Grossman and Helpman (1989), and Aghion and Howitt (1992) among others. Each of these categories is used to explain how growth can be sustained socially, even if the returns to private investments are diminishing. In other words, models are used to explain why aggregate returns to capital are constant. NGT models simply show that economic growth can be analytically represented in several ways, all providing quite similar results under strict parameterisations, suggesting that the different explanations are equally plausible. If this is the case, which of the above explanations, and set of assumptions, for an endogenous increase in the technological factor should be picked and why?

NGT has made important contributions to formal growth theory, articulating some representations of the underlying processes of development, but the fact remains that too many critical features of the economic system are treated as "given" within this literature. There is little recognition of the context-specific "non-economic" factors affecting economic activity, such as those highlighted by economic historians in different regional settings (Easterly 2002). In the NGT framework there is no evolution, no characterisation of agents leading up to aggregate behaviour, and no allowance for out-of-equilibrium dynamics. Further, the conceptual drawbacks of the use of Cobb-Douglas production function are not addressed (see note 13 above). The aggregation of supply (or a homogenous disaggregation) does not provide insight into the widely observed processes of structural change and industrial dynamics. Finally, the homogenisation of demand restricts an analysis of its role in economic development and growth.

research centres and they think they are achieving some understanding [of growth]. Maybe so, but it does not seem sharp enough to be embodied in a model"(Solow 1994a: 378). 
NGT does not provide a causal explanation of how technological change emerges or how it affects economic development and growth. Assumptions of representative firms, industrial sectors and/or institutions hide the real process of technological development under the veil of homogeneity. No account of the differences between various industrial sectors, firms, and institutions as structuring phenomena is made: differences in the technology used/produced and demand elasticity of outputs across sectors are crucial in explaining divergent developmental patterns. ${ }^{16}$ Finally, the "representative" rational individual assumption of NGT has been time and again persuasively challenged by a number of scholars (see for example Simon 1981; Conlisk 1996).

In the foregoing, we have discussed the main features and limitations of orthodox theory in understanding development and growth processes, especially at 'disaggregated' levels. The NGT is clearly an advance through its exploration of different patterns of endogenous growth including market imperfections and technological change. However, sources of technological development and the diversity of behaviour underlying these sources are largely neglected by mainstream theorists.

\subsection{Firms, Technological Change, Demand, and Institutions: Heterodox Approaches}

There is a large divide between the orthodox models' representation of economic growth and the development dynamics that drive it. While some major determinants of growth are considered in both theoretical modelling and empirical analyses, they are subject to a theoretical representation which does not allow an analysis of underlying mechanisms and heterogeneity. Technical change is treated as a driver of growth, however the way in which technical change occurs is not explored with sufficient attention to the micro-, firmlevel economic activity. ${ }^{17}$ In neo-classical theory, microeconomic phenomena are portrayed as stable at the macro level leading to an analysis of the allocation of resources at the macro level without analyzing changes in production and technical innovation at the firm level.

Some economists have attempted to address the shortcomings of the orthodox perspective on growth. Following Nelson and Winter (1982), evolutionary economists have built growth models focusing on the dynamics of firm-level and/or sector-level activity (focusing mainly on the supply side) and the consequences of these dynamics for the whole economy (see for example, Silverberg and Verspagen 1994; Fagiolo and Dosi 2003). Some evolutionary and other approaches have also emphasized the role of demand as complementary to the evolution of production patterns and micro-level behaviour. These perspectives include some level of disaggregation of economic entities, and allow for their heterogeneity in the analysis. Given this disaggregation, the development dynamic is interpreted as an unbalanced out-of-equilibrium process. Below we group and briefly consider two streams of this literature: the evolutionary approach to growth and technological change; and the "cumulative causation" theories developed within the neo-Keynesian framework.

\footnotetext{
16 On sectoral patterns of innovation see Malors (1997) and Pavitt's (1984) seminal work; on the role of sectors in growth see for example, Pasinetti (1981), Verspagen (1993) and Fagerberg (2000); on the relationship between sectors and demand elasticity in north-south growth models, see Cimoli and Soete (1992). On the role of firm organisation on development patterns, see for example von Tunzelman (1995).

17 Attention to micro-, firm-level economic activity is more adequately addressed in the evolutionary economics tradition beginning with Nelson and Winter (1982) and the innovation systems literature discussed below.
} 


\subsubsection{Evolutionary Growth Models: The Supply Side of Growth}

The process of economic growth, in broad terms, may be viewed as the product of the interactions between three main factors: productivity growth, demand, and co-ordination forces (Metcalfe, Foster, and Ramlogan 2002). Each of these factors is itself a product of interactions among heterogeneous forces at lower levels of analysis. The macro, aggregated factors can be derived from the micro-level processes, but the inverse is far more difficult to achieve (Carlsson and Eliasson 2003:435). The evolutionary approach takes the firm as its unit of analysis and focuses on the dynamics of firms' behaviour as the micro foundation of macro phenomena, while assuming bounded rationality and heterogeneity of agents. In addition, the evolutionary approach assumes continual emergence of novelty in ideas and agents as products of variation and selection processes (Dosi 1988).

The pioneering work of Nelson and Winter (1982) treats the firm as the primary agent of technical change, and thus the main driving force for growth. As discussed above, NGT models also consider technical change to be the driver of growth, but represent it in an abstract way with no account of the heterogeneous, non-maximising behaviour at the firm level. In contrast, Nelson and Winter (1982) apply an appreciative understanding of firms' 'routine' behaviour for building a model that focuses on innovation as a relative (behavioural) response to market conditions.

An important contribution of evolutionary growth theory is the central role of technological change within firms and the related novelty generation. ${ }^{18}$ Two types of models can be distinguished within evolutionary economics: models which account for embodied innovations occurring with investment in capital; and models which consider disembodied technical change occurring due to direct R\&D efforts of the firms. The way in which disembodied technical change is modelled can vary widely as it is a result of complex dynamic interactions between different types of knowledge and its application within different firms. Usually, a part of the innovation process is stochastic, but cumulative features of knowledge accumulation are also taken into account. Some models have introduced firm-learning in innovation routines, in both quantity and direction, which determines changes in R\&D strategies of firms.

It must be noted that if one moves away from the simplifying assumptions of neoclassical theory, the articulation of economic phenomena through mathematical modelling becomes more difficult. Similarly, once one assumes non-optimizing behaviour, a convincing account of satisficing behaviour needs to be developed. One may use the analogy of routines as "genetic" rules that characterise and differentiate firms' behaviour (Nelson and Winter 1982). But, it is still important to find a set of regularities which bounds the variety of routines. As we argue later, these regularities become manifest through an array of formal and informal institutions.

\footnotetext{
${ }^{18} \mathrm{It}$ is important to note that analysing technological change has a long tradition in economics, viewed as a dominant variable in processes of development and wealth creation since the industrial revolution. That it has been set aside after the contributions of Marx is probably due to an "historical accident". According to Pasinetti (1994), “...the roots of the appalling inadequacy of modern economic theory to investigate technical progress lies in a peculiar perverse accumulation of misjudgements made by the economic profession at crucial junctures in the development of economic theory when, for analytical reasons, a choice seemed necessary between equally possible, but alternative, lines of investigation" (Pasinetti 1994:2).
} 
According to Silverberg and Verspagen (1995: 18), evolutionary views have increased our understanding of development and growth processes only to a limited extent: " ....in the sense that they do not provide insight into exactly which factors play which role in the growth process." Nonetheless, the evolutionary perspective does provide a more in-depth understanding of the interactions between micro-behaviour and macro-emergent properties. This is important for exploring the dynamics of structural change at the macro level, the changes in industrial configurations, the incentives driving firm-level innovation, and the role of the institutional environment. This heterodox approach is more grounded in the complex reality of the economic system and provides us with some means to account for micro-level phenomena where stochastic events play a significant role.

\subsubsection{Structuralist/Kaldorian Growth Models: The Demand Side of Growth}

In line with the Keynesian tradition, Kaldor (1966), ${ }^{19}$ and others, ${ }^{20}$ emphasized the role of demand in economic development and growth. He based a substantial part of his reasoning on the concept of cumulative causation, which he used to relate the interplay between demand patterns, investment decisions, vintage capital, and productivity growth. Economic output increases through investments in sectors that induce increasing returns, which are in turn spurred by an increase in the demand for the goods they produce. In particular, Kaldor (1966) underlines three different processes that constitute demand in the economy: consumption, capital investment, and export demand. In simple terms, given the increasing returns to investment, growth is higher if internal consumption concentrates on sectors with higher returns and faster technical progress. A high demand elasticity with respect to international income from the goods produced by the sectors leads to a higher productive efficiency, which in turn should increase demand through a reduction in output price. Two parameters play a crucial role in Kaldor's perspective: income elasticity, an aggregate feature; and technical productivity, a firm- and sector-dependent micro (meso) feature.

Using a similar approach, Pasinetti (1981) attempts to understand growth as a function of sectoral interaction and change, representing the economy as composed of different vertically related sectors each with its own autonomous production process. If different sectors are assumed to be ordered in a vertical configuration, the final sector constitutes the final demand, and at the same time provides the labour input to all sectors of the system. Unlike the orthodox approach, Pasinetti's (1981) model does not assume a system in perpetual equilibrium. Instead, he models a dynamic system in which the intersectoral forces can keep the economy in a continuous out-of-equilibrium state. Equilibrium is only reached if all sectors produce at full capacity and there is full employment (which is not assumed). Hence, growth rates of individual sectors can be different, following labour and technological dynamics. This allows one to picture a shift in the economic system and its structural change. Second, no unlimited growth or steady state occurs due to changing demand conditions for

\footnotetext{
${ }_{19}$ See also the model in Kaldor and Mirrlees (1962).

20 The line can actually be traced back to development scholars such as Hirschman (1958), Myrdal (1957), Prebish (1950), and Singer (1950), who developed important concepts such as effects of industrial linkages, cumulative causation and terms of trade traps.
} 
each good. When the demand is met, either a shift in the sectoral composition occurs or there is a reduction in the supply of labour.

The structure of Pasinetti's model provides important insights into the composition of an economic system and how it affects development. The model can be used to understand differences in patterns of development across countries, or investigate the relevance of different patterns of technical change across sectors, or examine the consequences of internal and external demand shifts. In other words, it provides a 'meso' level interpretation of economic change and development, that complements (or may be complemented) with the 'micro' (supply side) approach of evolutionary understanding, and the more 'macro' cumulative causation perspective.

Following Pasinetti, some evolutionary models that endogenise technical change at the sectoral level have been able to relate growth patterns of the economic system to sectoral restructuring, country specialisation and international trade dynamics. ${ }^{21}$ Their macroframework is based on the balance of payment theory developed by Thirlwall (1979) - a formalisation of Kaldorian propositions on international demand and growth. Further, the economic system is composed of different open economies specialised in different sectors, each producing a different good with a different demand elasticity (in national or international market), and each with its own labour productivity. Thus, technological development, trade, price and wage dynamics in the different countries, composed of different sectors, affect their relative competitiveness and rate of growth. Both selection and innovation occur through sectoral evolution and technical change is predominantly deterministic, following a 'KaldorVerdoorn' law. The micro behaviour however is not specified.

In an attempt to bridge the micro insights of evolutionary modelling and the Kaldorian macro framework, Dosi et al. (1994) extend Kaldor's (1966) approach to consider different levels of aggregation together in a multi country setting. In their model, each country is composed of two sectors, each with its own set of firms. Further attempts in this direction have been made by Lorentz (2004), and Saviotti and Pyka (2004). Although these models are able to consistently link the different levels of aggregation in an economic system, they are unable to provide an explanation of the way in which the dynamics underlying the development processes are organised. Institutional settings, in which these dynamics occur and which spur or retard the dynamics, are better explained by alternate narrative-based approaches. These approaches emphasize context-specificity and the micro- (and meso-) level organization of innovative activity as two key elements determining growth. Such an approach developed by the innovation systems (IS) literature underlines the instrumental role of context-specificity but does not, as we argue in the next section, fully account for institutions and institutional change, hence fails to make the obvious link to the substantive institutionalist literature in economics.

\subsection{Innovation Systems}

A group of scholars including heterodox economists, economic geographers, and regional planners have developed the multi-scale concept of "innovation systems" to

${ }^{21}$ See, for example, Cimoli (1994), Los and Verspagen (2003), Verspagen (1993), and Verspagen (2002). A similar approach which also yields similar conclusions is the "technology gap approach" applied by Fagerberg (1987). 
highlight the importance of specific institutions and technological and organizational learning processes in economic development. Formal institutions, supporting technological and organizational innovation in firms, are central in this rapidly-growing stream of literature. However, these studies employ the notion of institutions with multiple interpretations and to varying degrees of lucidity. Most studies have focused on mapping the set of formal institutions which are crucial for successful innovative performance of a region/nation. Little emphasis is placed on dynamic analyses of system transformation and institutional change, which are essential from an economic development perspective.

Since its emergence in the late 1980s, the innovation systems concept has become one of the most popular frameworks to study technological innovation among economists and policy scholars. According to a recent literature survey, around 750 studies have been published on the subject, with half of them taking the National Innovation System (NIS) as their unit of analysis (Carlsson 2004). The other half is evenly divided among studies on Regional Innovation Systems (RIS) ${ }^{22}$ and sectoral/technological innovation systems. In this paper we will focus on the NIS literature. In the first part of this section, we provide an outline of the basic building blocks of the NIS concept as identified by its prominent proponents. The second part focuses on the definition and analysis of 'institutions' in the IS framework. The third part is a brief critique of the innovation systems literature in addressing issues of economic development from a dynamic systems perspective.

\subsection{National Innovation Systems: An Overview}

The pioneering studies on the concept of 'national systems of innovation' are due to Lundvall (1988), Nelson (1988) and Freeman (1987). The innovation systems framework captures the social character of the innovation process by embedding the innovative efforts of individual firms in networks of relationships with other organisations such as supplier firms, universities, research centres, government departments, financial institutions and endusers. ${ }^{23}$ The new knowledge required for innovation is generally created through joint efforts of the above knowledge generating actors operating in an institutional setting and with the support of formal institutional actors. This emphasis on "learning by interacting" is one of the cornerstones of the IS framework. Determinants of the diffusion of new knowledge or technologies into an economy are also included in a broad conceptualisation of the innovation system (see Lundvall et al. 2002; Edquist 1997). The emphasis on the 'national' scale stems from the understanding that the institutional contexts in which new knowledge is produced/diffused, and technological specialisation patterns, tend to differ across national borders. ${ }^{24}$ In addition, adopting this scale of analysis allows one to examine the impact of and implications for innovation policies framed at the national scale. Finally, NIS scholars advocate that the concept and framework should be kept relatively diffuse and general so as

22 See Doloreux and Parto (2005) for a critical overview of this literature.

23 The term innovation generally refers to technological innovation, however some authors have characterised innovation more broadly to include organisational innovations.

${ }^{24}$ This is doesn't imply that the NIS is not affected by the globally organized economic and research system, but highlights the importance of knowledge creation capabilities that need to be built in local firms through national policy focus and other institutional mechanisms for sustained economic growth. 
to allow adaptation to different contexts and regions (Lundvall 1992; Edquist 1997; Arocena and Sutz 2000).

The widespread diffusion of the NIS concept among students of innovation was given a crucial stimulus by the publication of two books in the early 1990s. The first book edited by Lundvall (1992) was an attempt to theoretically develop the national innovation systems framework further. The second book edited by Nelson (1993) adopted the complementary approach of empirical analysis by presenting case studies of innovation systems in fifteen countries. Our outline of the theoretical elements of the NIS concept is largely derived from the work done by Lundvall and his colleagues at Aalborg.

According to Lundvall et al. (2002), four theoretical elements were combined together to develop the national system of innovation concept:

"the neo-Schumpeterian reinterpretation of national production systems, empirical work based on the home-market theory of international trade, the microeconomic approach to innovation as an interactive process inspired by research at SPRU and, finally, insights in the role of institutions shaping innovative activities." (Lundvall et al. 2002: 216-217)

The national production systems concept has its roots in the French and Scandinavian structural economics tradition, where an economy is seen as a system rather than just a simple co-existence of different sectors. This literature pays significant attention to forward and backward linkages of producing units (see Cooke and Morgan 1998 and Kemp et al. 2000 for a synthesis of some of these concepts). The second element points to the nature of demand in an economy which partly shapes the technological specialisation pattern in small industrially developed countries, for example the Danish specialisation in dairy processing machinery (Andersen and Lundvall 1988). ${ }^{25}$ The interactive learning element entered the NIS concept because of substantial empirical evidence collected in the 1970s and 80s showing that innovation was strongly dependent on co-operation and co-ordination among a group of heterogeneous actors. 'Learning by interacting' was added to Arrow's (1962) 'learning by doing' and Rosenberg's (1982) 'learning by using' as an important factor in innovative performance of firms (Lundvall 1992). The fourth element in Lundvall at al.'s (2002) conceptualization refers to formal and informal institutions that form the context in which the interactive learning takes place (see also Johnson 1992; Edquist and Johnson 1997 for discussions on institutions in NIS literature). Here institutions are generally treated as distinct from other market or non-market organisations.

In order to appreciate the scope of the NIS concept, it is important to understand the main components of a NIS. The starting point for Lundvall (1988) is the set of firms and their linkages in a national system of production. Technological and organisational competence is built in this system through learning and generation of new knowledge which, together with appropriate institutionalization processes can signal the emergence of a national system of innovation. According to Lundvall (1992), the sub-systems to be included in the analysis and the boundary of the system must be left open as they will differ in different settings and applications. However, in general terms, one may consider the following organisational bodies as crucial elements of a national system of innovation:

25 One may also consider the natural resource endowments or features of a small country as partial determinants for the nature of demand and the pattern of technological specialisation. A case in point is Sweden which developed a strong wood-processing machinery sector. 
- Firms including organisations such as consortia of firms or sub-units of firms such as industrial R\&D laboratories

- Universities as sources of trained personnel and basic science

- Government sponsorred research centres as crucial catalysers of private-public interactions

- Investment banks and other supporting organisations in financial sector such as venture capital firms

- Relevant regulatory bodies such as patent offices or national/local government departments

- End-users, including public procurement by the government

The efficiency of a NIS is history-contingent and depends on the competence of these organisations in producing (and absorbing) new knowledge, and adapting to a rapidly changing external environment. It also depends on the nature of evolution of the structure and efficacy of inter-organizational links within the system as knowledge is accumulated, and to cope with changing pressures from the external environments. Finally, the adaptation of the institutional context is fundamental in facilitating learning processes for efficient functioning of a NIS.

\subsection{Institutions in National Innovation Systems}

According to Nelson (2002: 265), the "innovation systems idea is an institutional conception, par excellence." Most researchers in the NIS stream consider the role of institutions as central in an innovation system (Edquist 1997). References are made to institutions that facilitate and support technological innovation in most analyses of NIS (Johnson and Edquist 1997). However, we have not come across NIS studies that perform an in-depth analysis of institutions and institutional change. ${ }^{26}$

NIS scholars have historically associated different meanings with the term 'institutions'. A part of this literature views all types of organisational structures, including firms, universities and R\&D laboratories, and technology policy as institutions (see for example, Nelson and Rosenberg 1993; Niosi et al. 1993; Pavitt and Patel 1994; Niosi 2002). In this conception, firms and their R\&D laboratories (as institutions), and other non-market institutions supporting innovation, with linkages among them and the interactions between the institutions and their environments, can create an innovation system. Coherence between the diverse institutions is therefore essential for an IS to be efficient, and positive feedback between the different interrelated institutions is required to strengthen them. The importance of behavioural and other informal institutions such as the nature of trust and cultural habits in a society is rarely emphasized in this part of the literature.

In contrast, Lundvall and his colleagues at Aalborg treat specific institutions as parts of an "institutional setting or context" which shapes the learning process of firms and other organisations (Lundvall 1992). Institutions are then understood as "norms, habits and rules [that] are deeply ingrained in society and ... play a major role in determining how people relate to each other and how they learn and use their knowledge" (Lundvall et al. 2002: 220). Here, the institutional setting includes both formal arrangements, such as laws, intellectual

26 The work of Johnson (1988, 1992, 1997 with Edquist) is a notable exception. 
property rights regimes and labour market organizations, and informal arrangements such as the long-term or short-term perspectives of the agents and the nature of trust in transactions between the agents (Lundvall et al. 2002). Further, institutions are understood to possess the fundamental characteristic of "relative stability over time" (Lundvall 1992: 10). As a result, institutions provide the necessary stability and coherence required for ensuring the occurrence and success of innovation in firms. However, an understanding of institutions based on stability tends to overlook the importance of institutional change as a crucial part in the development of learning processes and in the broader systemic change. As we attempt to show later in this paper, institutional changes underlying the systemic transformation in newly industrialized countries of East Asia were central to industrial development.

An early analysis of the relationship between technological and, aspects of, institutional change in innovation systems literature is Johnson (1988). Drawing on the work of North (1981), Lachman (1970) and other institutionalists, Johnson points to the centrality of institutional change in long-term economic growth and attempts to draw parallels between patterns of change in technologies and institutions. However, he does not explore the multiple dimensions of institutions and the way they interact with one another to structure innovative activity. Neither does he delve into the nature of informal institutions that condition processes of development and growth (see also Johnson 1992).

Our interpretation of institutions resonates with and expands on the Aalborg conception of institutions (see Parto [2005a] for details). We propose a typology of institutions that ranges from informal to formal, and distinguishes between behavioural, cognitive, associative, regulative, and constitutive institutions. Drawing on elements of institutional economics, Edquist and Johnson (1997) have made a similar attempt to disaggregate institutions in an innovation system. They attempt to clear some of the conceptual ambiguity associated with the term institutions, and distinguish between economic and political; formal and informal; 'hard' and 'soft'; and 'basic' and 'supporting' institutions. They also discuss at some length the many different types of relations between innovation and institutions. However, their analysis of institutional change based on some of their taxonomy does not adequately explain system transformation processes which are of prime importance from the perspective of developing economies.

\subsection{Transformation of Innovation Systems and Institutional Change}

Recent work has highlighted that analysing the transformation and evolution of systems of innovation is an essential task as technologies are becoming progressively more complex and new techno-economic paradigms are emerging and becoming intertwined with one another (Galli and Teubal 1997; Metcalfe 2000). Studying the design, spontaneous emergence, and transformation of institutions to deal with the rapidly changing technological scenarios is critical to the study of innovation. This is particularly important if we start from the premise that the emergence of new technologies is only partly conditioned by institutions that stabilize older technologies.

Historical accounts of industrial development have demonstrated the crucial role played by national institutions in building competitive capabilities of firms within specific industries. Murmann's (2003) analysis of the German synthetic dye industry in the late $19^{\text {th }}$ and early $20^{\text {th }}$ century shows that institutional change was essential for industrial and innovative success: in 
particular, the creation of formal institutions such as new forms of public-private partnerships to "sponsor industrially relevant applied research" (Murmann 2003: 170); establishment of specialised research institutes; the formation of an effective German Chemical Industry Association and its crucial role in shaping new patent laws that forbid product patents on chemical products, but were severe on infringement of process patents. This perspective emphasizes the co-evolution of firm capabilities and technologies with institutional forms (Nelson 1994; Nelson and Sampat 2001; Murmann 2003). ${ }^{27}$ But as observed by Carlsson (2004), only a small percentage of existing studies on innovation systems have explicitly adopted a dynamic, historical perspective. Even a smaller percentage has analysed the formation of a new innovation system. Most importantly, an "analysis or discussion of the mechanisms through which institutions work", much less of how they change, is extremely rare in the literature (Carlsson 2004).

A dynamic perspective is crucial for change in economies locked-in to inefficient systems of innovation. Building of new innovation systems or transformation of older systems through 'capacity building' is a main objective of a good portion of development studies. However, the majority of applications of the IS framework to development attempt to transpose a well-functioning innovation-system model based on developed countries onto developing countries (Arocena and Sutz 2003). Such prescriptive analyses tend to overlook the specificity of the local institutional context and its (in)adequacy in fostering learning and innovativeness in firms. For example, in the innovation systems literature, there is relatively little analysis of institutions acting as obstacles to innovations as is commonly the case in underdeveloped countries. Corruption, incidentally, is one such (informal) institution. As a result, little insight is gained into the mechanisms of the necessary institutional change required for bridging the 'learning divide' (Arocena and Sutz 2000) or the technological divide (de la Rive Box 2001). Bridging this gap requires nurturing learning capabilities and creation of demand for new knowledge in less developed countries (Arocena and Sutz 2003; Johnson and Lundvall 2003). Further, an institutional context for facilitating positive feedback loops among heterogeneous actors is required to develop learning capabilities as a necessary feature of an innovation system. To this end, a detailed analysis of the less formal behavioural and cognitive institutions is highly beneficial in assessing the sufficiency of human and social capital to nurture innovative activity.

Recently, a set of studies have developed the concept of 'local productive arrangements' to highlight the lack of articulation (from a learning/innovation perspective) among heterogeneous actors in local production agglomerations in Brazil and Uruguay (Cassiolato et al. 2003). The starting point of these studies is the prevalence of such arrangements in underdeveloped contexts, instead of dynamic production and innovation systems where "articulation, interaction, co-operation and learning processes" work well (Lastres et al. 2003, p. 23). The challenge then lies in designing and implementing policies that are likely to transform these inarticulate productive arrangements into well-functioning dynamic innovation systems. The first step in understanding the conditions that will promote such a

27 According to Murmann (2003: 22-23), “Two evolving populations co-evolve if and only if they both have significant causal impact on each other's ability to persist. ... Whether a coevolutionary process is beneficial or harmful for the parties involved depends on the particular causal relationship that links the parties; therefore, this relationship needs to be specified in the empirical analysis." 
transformation undoubtedly involves mapping the set of institutions and firm capabilities in the productive arrangements. The equally important second step concerns working with and changing relevant institutions in order to create the 'right' conditions. As a final point, pressures from the globalisation of production and, to a smaller extent, of innovation activities are forcing many nations and regions to reconsider older policy prescriptions. This scenario increases the urgency of studying transformation processes from an institutional perspective to better understand how existing institutions within national boundaries (can) change and adapt (Caracostas and Soete 1997).

In the next section we attempt to draw attention to the largely neglected elements of innovation systems, i.e., institutions, by adapting concepts from old and new institutional economics. We provide details on how the innovation systems approach should be enriched to better inform public policy, with the assumption that even under post-Fordism and in current globalized trade regimes governments can play a significant role in shaping economic and industrial development.

Finally, in order to develop ideas of institutional analysis in national innovation systems, we propose a theoretical representation of development and growth, similar to the one adopted by Dosi et al. (1994) and Saviotti and Pyka (2004). This representation takes both 'qualitative change' and 'structural change' of an economic system into consideration. Structural change occurring at the sectoral level goes hand in hand with the qualitative changes taking place at lower levels of the system, such as at individual cognitive levels, in firm-level behaviour and in other organisations. Developing a coherent account of change requires paying attention to the specific characteristics of institutions that structure interrelations at different levels; intertwine social, economic and political systems; and act as mechanisms or channels through which governance is exercised at different scales. To do this, as outlined below we need to superimpose an arbitrary division between levels, systems, and scales. The process requires an understanding the entire range of formal and informal institutions.

In addition, drawing on the interpretative framework suggested by Kim and von Tunzelmann (1998) we propose analysis and interpretation of development processes through 'alignment' of different levels of interaction at different territorial scales of governance, i.e., sub-national, national, and supra-national. For example, the development of Taiwanese or South Korean IT industries may be explained through the role of policies that have been oriented to the alignment of external relations, the national innovation system and the local technological system. In other words, the process of production and innovation taking place inside the Taiwanese firms must be viewed in conjunction with their local institutional setting, the relevant economic sector, the national system of innovation, and international pressures/relations.

\subsection{Institutions and Institutional Analysis}

In a recent book with examples on outcomes of development prescriptions from many tropical countries, Easterly (2002) argues that development failures are not due to economic failures but rather due to the (institutional) context of applications. Conducting institutional analysis to investigate success or failure in economic development should go beyond focusing on specific institutions such as government agencies, business associations, or cultural values. 
It should pay attention to an economy's full range of identifiable formal and informal institutions, including networks and associations, to examine their inter-relations; reinforcing or neutralizing mechanisms; their relative significance within the system; and the different degree to which each institution may be influenced through policy or other intervention. Institutional analysis, as we see it, bases itself on multiple disciplines to capture multiple causalities and relies on substantial use of narratives as illustrative accompaniments to formal models.

Indispensable in understanding multiple causalities are narratives from different social scientific perspectives including history, sociology, and political science. Economic historians have provided systematic views of economic development in different eras (Kuznets 1966; von Tunzelmann 1978; 1995). Historians of technology tell us how new technologies (or technological systems) emerge and are subsequently improved and diffused, through the rich detail in their case studies of specific technologies (see for example Constant 1980; Hughes 1983). Sociologists and political scientists have illuminated the role of power and the nature of interactions through formal and informal institutions between different interest groups that determine the choice of a particular technology over others and shape subsequent trajectories of technological development (see Bijker 1995; Winner 1986). Economists can develop formalized causalities and explore outcomes based on modelling quantifiable relations between carefully selected factors, or develop theoretical frameworks to make sense of diverse interactions between the components of an economic system and between the system and its environment. A basic premise of this perspective is that innovation, industrial development, growth, and more generally economic activity do not occur in a socio-political vacuum.

The "interconnectedness" and inevitable complexity implied in our premise leads us to focus on two aspects of industrial development. First, because of complexity, industrial development policy making is based on a series of simplifying assumptions. Second, industrial development policy can include more or fewer actors/stakeholders. One key assumption that has returned to dominate the thinking behind much of economic policy making is the belief that there is a direct and unidirectional relationship between business and societal well being. That is, if business firms do well, they create more wealth and generate more jobs. This was certainly true of the post WWII years in Europe when corporate tax rates were substantially higher than they have been since the early 1990s and when the state deemed its business to ensure societal welfare by providing public services. Starting in the mid-1980s, concerted efforts have been made by an increasing number of governments to offload most of their 'costly' public service functions and for providing new impetus for economic growth. Much of the discussion on the move from government to governance, at least in the context of North America and northwestern Europe, has referenced the delegation of formal state functions to non- and quasi-governmental entities, accompanied with neoliberalism as a dominant state political tendency to facilitate the move from the "Keynesian welfare national state" to a "Schumpeterian workfare regime" (Jessop 1993, 2003).

On the issue of inclusion of actors in the policy making process, the degree of inclusiveness is determined by the 'mode of governance', which may be more or less hierarchical. Under the umbrella of governance there have been numerous discussions since the early 1980s among policy makers and social scientists alike on collaboration, cooperation, 
and coordination. This discussion was partly spurred by the belief that interdependencies among actors in markets, networks, and hierarchies have increased both in number and strength. If we simplify the notion of governance to mean 'the way human communities (i.e., organizations, polities, and cross-polity regions) organize themselves’ (Parto 2005b), it follows that studies of the economic system need to include many different kinds of actors who have to relate to one another, and who all contend for (or defend) a piece of the proverbial pie, action, or power. A human community organizes itself through formal and informal institutions that collectively act as structuring phenomena. But, this begs the question: what are these institutions and where are they manifest?

\subsection{Institutions ${ }^{28}$}

Our starting point is that the institutions through which governance (including economic development policy-making) is exercised are reflections of learning in its broadest societal sense. However, once established, institutions structure (constrain and facilitate) further learning in a continuous and interactive auto-catalytic process. While the interest in institutions of governance by economists and political scientists faded somewhat in the mid$20^{\text {th }}$ Century, it remained continuously present in sociology and is reflected in works of Cooley, Durkheim, Spencer and Sumner around the turn of the $19^{\text {th }}$ century, to Weber (1924), Hughes (1939), Davis (1949), Parsons (1990), DiMaggio and Powell (1983), Jessop (2001), and Scott (2001) among numerous others. Many of these writers have been influenced by, or rebelled against, ideas put forward by Marx in mid $19^{\text {th }}$ century. The resulting diversity of conceptualizations of institutions originating in sociology, political science and economics has generated a literature on institutions that is extensive but difficult to operationalize.

A close look at the many definitions of institutions reveals three important distinguishing features. First, some definitions underline the territorial scale of governance (Krätke 1999, Ostrom 1999, Young 1994, 2002). Second, a number of these definitions refer to institutions as being manifest in individual behaviour in the society at large (Hamilton 1932, Parsons 1990, Krätke 1999, Veblen 1919), within organizations (Commons 1924, March and Olsen 1984, Coriat and Dosi 1998), among organizations (Ostrom 1999), and among nations (Young 1994, 2002). Finally, one can detect varying degrees of emphasis on social, economic, or political aspects of institutions. What comes through this grouping of definitions of institutions is that they can be more or less formal phenomena that structure different levels of inter-relation, territorial scales of governance, and systems (or "spheres", in the words of Max Weber). Viewed in this multi-layered fashion, the task of unpacking the complexity presented by the diverse definitions of institutions becomes more manageable. A summary of the working definitions for levels, scales, and systems is provided in Table 1. 
Table 1. Levels, Scales, and Systems

\begin{tabular}{|c|l|}
\hline $\begin{array}{c}\text { Levels of inter- } \\
\text { relation }\end{array}$ & $\begin{array}{l}\text { Individual: Among individuals at large based on interpersonal } \\
\text { interdependence where many actors are involved. } \\
\text { Organizational: Within organizations to secure internal cohesion and } \\
\text { among organizations to ensure adaptability of an organization to be } \\
\text { compatible with others in its operational entity (e.g. in a production chain). } \\
\text { Further, an organization's de facto independence but social interdependence } \\
\text { on other organizations. } \\
\text { Societal: Among operationally autonomous (or closed) functional systems } \\
\text { each with its own autopoietic codes, programmes, institutional logic and } \\
\text { interests in self-reproduction. }\end{array}$ \\
\hline $\begin{array}{c}\text { Scales of } \\
\text { Governance }\end{array}$ & $\begin{array}{l}\text { Local (subnational), national, international (between nationally constituted, } \\
\text { functionally differentiated institutional orders), transnational (passing } \\
\text { through national boundaries), and global (covering the globe as a whole). }\end{array}$ \\
\hline Systems & $\begin{array}{l}\text { A society may be defined in terms of its social, economic, political, and } \\
\text { ecological spheres or systems. A subsystem contains parts of all systems. }\end{array}$ \\
\hline
\end{tabular}

Source: Parto (2005a)

"Levels of inter-relation" is borrowed from sociology and refers to inter-relations at the individual, organizational, and societal levels. "Scales of governance" is used in sociology, political science, and administrative studies to capture the territorial dimension of governance. "Systems" is a notion borrowed from studies of systems dynamics (and from Weber's notion of spheres) and is used to bring interconnectedness into perspectives of governance. The notion of systems is particularly useful in dealing with complex and multi-dimensional processes such as those underlying innovation, which require studying economic activity in specific contexts.

The categorization in terms of levels, scales, and systems is constructed and employed to come to terms with the complexity of the fundamental question: how do we account for institutions in analyses of policy aimed at societal change? Answering this question has important implications for further research and policy. In research, careful categorization of institutions based on levels, scales, and systems enables one to investigate the same problem or research question in different contexts, expect different findings due to context-specific institutional landscapes, and identify the most relevant factors or variables in a given context. In policy making, an in-depth appreciation of the collective role of context-specific institutions is likely to minimize the possibility of designing unsuitable policies or setting unrealistic policy objectives. And, in policy implementation, institutional analysis can provide a better understanding of why in some contexts some policies succeed more than others in meeting their objectives.

The categorization in Table 1 provides a useful basis for working with the notion of institutions. Applying the levels-scales-systems perspective to institutions yields a typology of institutions as follows:

Behavioural: Institutions as standardized (recognizable) social habits - manifest in activities of individuals and groups as shared social norms

Cognitive: Institutions as mental models and constructs or definitions - based on values and embedded in culture

28 This section draws extensively on Parto (2005a, 2005b). 
Associative: Institutions as mechanisms facilitating prescribed or privileged interaction among different private and public interests

Reuglative: Institutions as prescriptions and proscriptions

Constitutive: Institutions setting the bounds of social relations

As important as this disaggregation of institutions is in identifying them, more important is the range of formality and scope that it depicts, particularly when we view institutions as phenomena that bind together and stabilize inter-relations at different levels, governance at different scales, and systems (see Figure 1). ${ }^{29}$

Figure 1. Scope and Formality of Institutions

\begin{tabular}{|l|c|c|c|c|}
\hline $\begin{array}{c}\text { Behavioural } \\
\text { Institutions }\end{array}$ & $\begin{array}{c}\text { Cognitive } \\
\text { Institutions }\end{array}$ & $\begin{array}{c}\text { Associative } \\
\text { Institutions }\end{array}$ & $\begin{array}{c}\text { Regulative } \\
\text { Institutions }\end{array}$ & $\begin{array}{c}\text { Constitutive } \\
\text { Institutions }\end{array}$ \\
\hline $\begin{array}{l}\text { Low Societal } \\
\text { Scope and }\end{array}$ & & $\begin{array}{l}\text { High Societal } \\
\text { Scope and }\end{array}$ \\
Formality \\
$\quad$
\end{tabular}

Institutional analysis to inform policy in a mode of governance committed to nurturing innovation and economic growth, for example, should begin with the specification of the context (comprising levels, scales, and systems) in which the institutions are to be studied. Further, it requires differentiating between formal and informal institutions since different levels of formality (tangibility and scope) require different methods, or mixes of methods, of analysis and policy approach. It is important to distinguish between each institution type and its catalyst(s). For example, the introduction of a new regulation on borrowing is not an institution but a catalyst. The catalyst may, or may not, result in an institution embedded in society as a structuring phenomenon. If the regulation is not enforced and complied with widely in the society, it is not, for our intents and purposes, instituted. Similarly, an associative institution may come to be as a result of an alliance forming between private or private and public interests. If the alliance persists and actively structures inter-relations, it can then be said to be an associative institution. The next section sketches out how the typology in Figure 1 may be applied to studies of economic development.

\subsection{Institutional Analysis}

So far in this paper we have provided descriptive accounts on theorising in development and growth in economics and innovation systems literatures. The two literatures share a focus on economic growth though innovation system scholars have also paid attention to issues of capacity building for development in a variety of contexts. The introduction of context specificity is a welcome addition in framing the question of why some economic conglomerations, e.g., regions or nations, are more successful and enjoy higher and more sustained growth than others. However, we have also indicated that the treatment of the role of institutions in the literature on innovation systems does not sufficiently explain why some regional or national economies fare better than others, let alone provide insights on

${ }^{29}$ See Parto (2005a) for a detailed discussion of institutions at different levels, scales, and systems. 
steps that can be taken in a given context to foster an institutional transformation. In the preceding section we articulated a framework for a more in-depth understanding of the role of formal and informal institutions in understanding processes of economic development and growth.

In the remainder of this section we extract elements from the case studies of Taiwan and South Korea in attempt to illustrate how our framework may be applied to incorporate more contextual depth for understanding the different sources of growth and the interactions between them. On a cautionary note, our illustration through a re-reading of the two case studies carried out by others is far from conclusive and must be buttressed by future detailed case studies conducted using the institutional framework presented here. The discussion below draws on the in-depth case studies developed by Wade (1990), Hassink (1994), Kim (1997), Amsden (2001), and Chang (2003). Specifically, we attempt to superimpose the institutional typology outlined above onto the two cases. ${ }^{30}$

\section{Taiwan}

From 1895 until World War II, Taiwan was under Japanese colonial rule. The Japanese built up a well-functioning education system and invested in health and infrastructure. After the Chinese took over in 1945, the provincial government of Taiwan had exercised a significantly higher degree of autonomy than other Chinese provinces under the Nationalist government's rule. This autonomy was reflected in a lower rate of inflation than the mainland, a separate currency (instituted in 1945), and an independent monetary policy as well as policies on trade and transport. With the arrival of the central government in Taiwan after the Chinese Revolution of 1949 a period adjustment and reorganization ensued: a new administrative structure was defined to accommodate the provincial administrators and the Nationalist apparatus.

The central government gradually assumed control with support from the United States through development aid and the establishment of the Economic Stabilization Board (ESB) in 1951 which acted to neutralize and eventually eliminate (in 1953) the provincial government's Production Control Board. From 1953 ESB formally assumed responsibility for preparing plans, formulating monetary, fiscal, and trade policy; coordinating military and civilian expenditures, formulating the expenditure budget for the counterpart funds; screening private investment applications, and approving all large loans from domestic banks as well as all foreign loans. Two more government agencies were set up in 1953. The Foreign Exchange and Trade Commission was charged to set exchange rates, allocate foreign exchange, and govern over other trade policy issues. The Commission made foreign currency available at below the market rate to the domestic producers. The second agency, the Industrial Development Commission was responsible for identifying industrial projects and help with start-ups. The two agencies played an instrumental role in encouraging the emergence of a domestic production base.

It would be naïve to view the transformation of Taiwan from an underdeveloped to a developed economy as smooth. In addition to conflict between the provincial and the central government administrators, the process was also riddled with conflicts over the direction for

\footnotetext{
30 The case of Taiwan is largely derived from Wade (1990) and to a lesser extent from Amsden (2001). The information on South Korea is drawn from Hassink (1994), Kim (1997), and Chang (2003).
} 
economic policy fought by two rival factions within the government. The first group stood for a balanced budget, no trade deficit, more consumer goods imports and fewer capital goods imports. This group also wanted more public sector control of economic activity and a dominant role for public enterprises. The second group argued for reduced government control of foreign trade and increased competition among domestic firms. The first group controlled the banking system and was hence able to frustrate the attempts by the second group to bolster a flourishing domestic private sector supported by cheap and accessible funds. However, with technical and monetary support from the United States, the second group was able to secure the necessary funds to set up a number of successful private sector ventures including a plastics factory, a window glass factory, and a man-made fibre factory. Perhaps more significantly the second group supported the Taiwanese president's belief that retaking the mainland was the number one objective but it could only be done once Taiwan had built up a strong industrially prosperous economy: Such an economy would unite the mainlanders with the Taiwanese in rallying behind the president.

The quest for building a domestic industrial base drew on support from mostly American-trained engineers and wartime public servants keen on expanding the private sector and reducing the size of state-owned enterprises. A process of adjustment started in 1958, including significant personnel changes in top government jobs, to make Taiwan the showplace for the free enterprise system in Asia. 'Industrializers' assumed important positions in the government and took control of ESB. Later in 1958, ESB was dissolved and its responsibilities were given to the already existing Council on U.S. Aid (CUSA). Reforms that followed included the unification of exchange rate, easing of import and export controls on many items, more accessible loans to private industry, and increased incentives for exporting. The incentives for export consisted of greater availability of export finance and of duty rebates on the import of items to be processed into exports.

\section{South Korea}

As with Taiwan, Korea's achievements are rooted in its history and a series of catalytic events. In pre-modern times, Korea was renowned for the wealth of its educational institutions and achievements in sciences. While under Japanese colonial rule from 1910 to 1945, Korea's manufacturing sector grew annually at an average of 9.7 percent. The Japanese also developed relatively sophisticated fiscal and financial systems and invested heavily in education, infrastructure, and health. However, from the fall of Japanese colonial rule in 1945 to the end of the Korean War in 1953 South Korea had lost two-thirds of its industrial capacity (World Bank 1993:127). The most recent transformation of South Korea from a largely agrarian to a highly successful industrial economy began in earnest in the early 1960s. Until the mid 1990s the average growth rate was 9 percent, raising GNP per capita in 1995 prices from $\$ 87$ in 1962 to $\$ 8,483$. The underlying determinants of this transformation have been identified as the turbulence created by the Korean War, a historically strong role of the government, land reform, creation of large export-oriented conglomerates (chaebols), Korean work ethics and, as with Taiwan, Confucian cultural values and the geopolitics of American anti-communist foreign policy.

According to Kim (1997), Korea's success in industrialization is attributable, to a large extent, to Park Chung Hee who seized power in 1961 and was deeply committed to 
transform Korea from a subsistent agricultural economy into an industrialized one. He created a highly centralized and strong government to plan and implement his vision of the new Korea. Heavy-handedly, the government directed industrial activity through licensing. The commercial banks were nationalized and "savings" for much needed investments were created by borrowing heavily from abroad. Park's military style moral values and discipline were reflected in how Korea's industrial development was regulated through a system of rewards and sanctions. To set an example, undesirable rent seeking behaviour by private sector actors under the previous regime (1948-1960) was dealt with threats of prosecution early on during Park's rule.

Other factors with significant role in the transformation of Korea include the institutional legacy of Japanese colonial rule (as with Taiwan) from 1910 to 1945. Many Korean technocrats were Japanese trained and capable of emulating Japanese-style organizational and economic management. Following the Japanese model Korea pursued an industrial policy that nurtured big business through subsidies and other incentives to become an engine of technological learning. The Korean government emphasized export orientation, challenging the private sector to create self-induced but creative crises, and promoted technologically advanced heavy and chemical industries while repressing labour unions. It was not until the late 1970s that the impact of Korean imports on foreign, particularly American, markets was felt and viewed as a threat to American domestic industry. Korea in the meantime had managed to establish a solid, export-oriented domestic economy consisting of a substantial traditional base including auto/auto-parts production, shipbuilding and set the foundation for a cutting-edge electronics sector.

Korea's successes came under strain during the 1980s due to a general slow-down in the world economy: rising labour costs despite the government repression of organized labour and increased competition from other newly industrializing countries; reluctance of developed countries to transfer technology to Korea; and international pressure to establish and enforce a strict copyright and patent laws system. Stricter copyright and patenting system effectively ended imitative reverse-engineering of foreign products, a practice that had made a significant contribution in Korea's technological learning.

The pressures on the Korean economy during the 1980s prompted the government to introduce a series of structural measures to sustain economic growth. A policy of economic democratization was put in place through the Fair Trade Act of 1980 to curb the powers of the chaebols which by then had grown into monopolies that partook in creating scarcities, price gouging, and predatory behaviour in the domestic market. The Act was revised in the 1990s to encourage the chaebols to compete in the emerging liberalized global market. The government also focused its attention on promoting SMEs which had been a neglected component in managing the economy during the 1960s and 1970s.

The development trajectories of Taiwan and Korea are attributable to two main factors: a grand vision of the country as a modern industrialized state by its rulers, and geopolitics. In the case of Taiwan, the 1958 air and sea battles with China over the possession of the Quemoy island prompted the United States to persuade the Taiwanese president to adopt a defensive stance and that Taiwan would not attempt to recapture the mainland. This agreement with the United States allowed the Taiwanese government to focus more attention on economic development instead of militarisation. Further, the agreement coincided with 
important personnel changes within the government, driven by internal politics rather than a conscious plan. The net outcome of these developments was a government committed to building an industrial base and maintaining a market-driven production system. Finally, there were significant amounts of U.S. Aid to scaffold the government's efforts. In the case of Korea, it is widely accepted that proximity to China and North Korea played quite significant roles in making South Korea a key recipient of "favours" and development aid from the United States.

Table 2 - Typology of Institutions in Taiwan and Korea ${ }^{31}$

\begin{tabular}{|c|c|c|}
\hline Institution Type & Taiwan & Korea \\
\hline Behavioural & $\begin{array}{l}\text { - Confucianism (respect for } \\
\text { hierarchical structures and valuing } \\
\text { hard work) }\end{array}$ & - Confucianism \\
\hline Cognitive & $\begin{array}{l}\text { - Importance of Education, } \\
\text { Industrialization, Mass Production, } \\
\text { and Competitiveness (as opposed to } \\
\text { welfare as the source of well being)a } \\
\text { - Importance of Knowledge-based } \\
\text { Assets } \\
\text { - Export Orientation }\end{array}$ & $\begin{array}{l}\text { - Importance of Education, } \\
\text { Industrialization, and Mass } \\
\text { Production (Chaebols), and } \\
\text { Competitiveness } \\
\text { - Importance of Knowledge-based } \\
\text { Assets } \\
\text { - Export Orientation } \\
\end{array}$ \\
\hline Associative & $\begin{array}{l}\text { - Industrial Associations } \\
\text { - Government-business associations } \\
\text { through Deliberation Councils } \\
\text { - Farmers and Irrigation Associations }\end{array}$ & $\begin{array}{l}\text { - Industrial Associations } \\
\text { - Government-business association } \\
\text { through Export Promotion } \\
\text { Meetings }\end{array}$ \\
\hline Regulative & $\begin{array}{l}\text { - Selective industrial and trade policies } \\
\text { (SIT) } \\
\text { - Regulations } \\
\text { - State-owned Enterprises } \\
\text { - Regulations to cap payment of } \\
\text { licensing fees and royalties for } \\
\text { imported technology }\end{array}$ & \begin{tabular}{|l|} 
- SIT \\
- Regulations \\
- Economic Planning Board \\
- State-owned Enterprises \\
- Nationalized Commercial Banks \\
- Provision of Targeted Loans \\
- Tariff and Tax Exemptions, \\
Accelerated Depreciation \\
- Linking issuance of import \\
licences to export performance \\
\end{tabular} \\
\hline Constitutive & $\begin{array}{l}\text { - Land Reform } \\
\text { - Martial Law (until 1987) } \\
\text { - Democratization (after 1987) } \\
\text { - Property Rights Regime }\end{array}$ & $\begin{array}{l}\text { Land Reform } \\
\text { - Property Rights Regime } \\
\text { - Democratization (after 1987) }\end{array}$ \\
\hline
\end{tabular}

${ }^{31}$ As stated earlier, grouping institutions into these five types can be done only very loosely and for the purposes of taking account of the levels, scales, and systems at and through which institutions are manifest. The type attributed to each identified institution denotes the main, rather than the only, characteristic of the institution. 
The institutional transformation underlying the ascent of Taiwan and South Korea to the status of newly industrialized economies can be explained through the typology of institutions introduced in the preceding section. Hassink (1994) suggests that Taiwan's (and South Korea's) success is due to a combination timely policy making combined with historical and cultural factors. For a long time Taiwan was under the colonial rule of Japan which ended with the Second World War. Chowdhury and Islam (1993:35) have argued that Taiwan's economy benefited significantly from this period of colonization. In the case of Korea, much of the industrial base and infrastructure created by the Japanese was destroyed during the Korean War. A new industrial base was to be created during the 1950s and 1960s through generous development aid from the United States. Certainly, this provision of development aid and industrial expertise was guided significantly by geopolitics: predominantly the determination to fight communism on all fronts.

The availability of development aid, though necessary, is not sufficient to explain Taiwan's success in industrialization. According to Chowdhury and Islam (1993) and Vogel (1991), cultural values based on Confucianism played an important role in providing a stable environment for industrial policy implementation. Confucianism emphasizes the value of hard work, self-cultivation, self-improvement, social harmony and cooperation. At an individual level these values translated into attention to education as a basis for success and respect for authority. While difficult to prove, one may conjecture that the combination of cultural values and large development aid are largely responsible for Taiwan's success. The catalyst for these two important factors to work, however, has been a reflexive interventionist industrial/economic development policy. Over time, the interventionist role of the government has co-evolved with changes in the internal and external environments. ${ }^{32}$

Government intervention has been aimed at creating a stable business environment in which the markets function efficiently. Establishing a property rights regime, labour and capital markets, low inflation through balanced government budget and strict monetary policy, as well as absorbing unfavourable externalities and ensuring a relatively high degree of foreign competition through liberalized trade are among the institutional measures taken by the government to manage economic development. The conflicts inherent in instituting these measures were checked by the hierarchical and authoritarian socio-political system and through sustained attempts by the government to engage business interests in economic development policy making.

Adopting the multi-dimensional institutional perspective as we have proposed in this paper emphasizes the key role played by the existing institutional landscape in facilitating the transition from 'underdeveloped' to 'developed' through industrialization. As we noted in our brief reviews of Taiwan and Korea, significant (formal) institutional capacity was accompanied in each case with a host of culturally-based and historically contingent informal institutions. Both the Taiwanese and the Korean society had the benefit of longstanding institutions that effectively structured inter-relations at all levels. Respect for power and

\footnotetext{
32 Our use of the term "interventionist" encompasses both the liberal and paternal approaches to economic management. A less regulated market does not mean that the government is not intervening. Rather, it implies that the government is intervening in the workings of the market by not taking action while remaining very much in charge as governments of Taiwan and South Korea, for example, have been doing since before their recent industrialization processes began.
} 
hierarchy combined with ethical values on the virtues of hard work were and continue to be important behavioural institutions, indispensable for societal transformation of the type experienced in Taiwan and Korea. Aspiring to become self-reliant and economically prosperous fits well with what we have described as cognitive institutions or mental models.

The importance of private and private-public collaborative arrangements as key to the economic transformation of Taiwan and Korea has been recognized and widely documented. In our typology we referred to these partnerships as associative institutions. Both governments actively intervened in the working of the market by introducing regulations and later removing them in attempts to guide and steer the behaviour of economic agents. These dynamic policy making efforts were simultaneously responsive to changes in the external environment and to the business interests inside the country. The interaction between the private sector and the government generated measures that broadly regulated interactions and transactions. In our typology we refer to these measures as regulative institutions. Finally, both countries underwent land reform and heavy-handed military rule. The military's grip was loosened significantly in 1987 in both countries. In response to pressures from the industrial North, both countries established intellectual property rights regimes to address objections and threats of economic sanctions by the North. Since these measures set "the bounds of social relations" we classify them as constitutive institutions.

\subsection{Conclusion and future directions}

Based on our reviews, we have illustrated that the somewhat crude representations of economic activity through the lenses of orthodox growth models have been significantly improved upon by heterodox, mainly evolutionary, approaches in economics which have drawn attention to the non-macro elements. Nelson and Winter (1982) and others have underlined the importance of innovative activity at the firm level while technological innovation at the meso level has been studied from a systemic perspective by Lundvall (1992) and others through studies of innovation systems. The latter studies have drawn attention to the role of institutions without, however, providing a sufficient basis for defining the necessary attributes and weights to distinguish among different types of institutions.

That technology and institutions "matter" in economic growth is a given in all orthodox and heterodox economic theories. Most post-exogenous arguments about growth share, to varying degrees, the perspective that economic development is a complex, multifaceted process; and that technological change, firm behaviour, and institutional characteristics collectively shape the development trajectories that generate growth. The research agenda that has emerged from this perspective is wide ranging and in its specialized form can be rather overwhelming to the average reader or policy maker without significant intellectual investment. We have argued in this paper that formal models of economic growth by themselves cannot illuminate the development process satisfactorily, particularly in providing explanation for institutional change that undergirds economic development. The New Growth Theory has in most cases marginalized institutions, which are sometimes assumed to justify the behaviour of the modelled variables or equation properties (Romer 1994; Mankiw et al. 1992). The evolutionary approach of Nelson and Winter (1982) has concentrated on micro behaviour at the firm-level and on the role of technological change. Even then as noted by Silverberg and Verspagen (1995) in a review of evolutionary growth 
theory, our knowledge of the underlying dynamics of economic development/growth has not increased significantly. The Kaldorian approach introduces some institutional features at the macro level, but the focus on sectoral dynamics essentially boils them down to a demand feature and its cumulative causation effects. The role of technology and innovation at the meso-level has been closely examined through studies of industrial clusters/districts, and innovation systems at different scales, e.g., regional or national. These studies have demonstrated that innovative capabilities of firms depend upon the institutional context, but their focus has largely been on mapping the set of supporting formal institutions. As a result, an in-depth analysis of the gradual formal- and informal-institutional change occurring in parallel with technological and organizational change remains elusive. A few scholars have attempted to explore parts of this puzzle (Zysman 1994; Petit 1999; Katz 2004), but a comprehensive study that gives equal importance to all pieces of the puzzle, especially institutions, is yet to be attempted.

As we have tried to illustrate in this paper, underlining the centrality of institutions in economic (and innovative) activity does not imply that all institutions are important all of the time. We have stressed the importance of identifying the institutional dimensions of the industrial development and growth as a first step in determining which institutions are observable for research purposes and controllable from a policy making perspective. This approach, while leaving room for random events and unintended outcomes, can lead us to better understand why as well as how change occurs. The approach is particularly useful in situations where the societal and/or policy intent is to effect change toward a preferred socioeconomic state, including development and sustained growth, or toward more desirable technologies or technological regimes, for example.

Amsden's (2001) “Assets Approach to Industrialization” comes closest in attempts to provide a frame of analysis to capture development and growth dynamics over time without losing sight of "non-economic" factors. We have argued that these non-economic factors are in fact a set of pre-existing institutions and new institutions that are products of deliberate change induced largely through government intervention. A main feature of this argument is our take on institutions as structuring phenomena and manifest at different levels of interrelation, scales of governance, and systems. A second important feature is that institutions are reflections of learning in its broadest societal sense by individuals and organizations. Institutions can be products of societal self-organizing processes and agent-induced actions including public policy. A major driving force in the great leaps forward by Taiwan and South Korea in economic development and growth has been policy learning. In both cases, a progressively sophisticated approach to economic development was adopted: from the relatively "simple" import substitution policies of post WWII years to export-oriented industrialization through industrial policies of the late 1960s to the 1980 s, and eventually to the present-day innovation policies.

In our brief reviews of the case of Taiwan and South Korea we have attempted to show that the advances made by the two countries to become newly industrialized economies would not have been possible without the integrated webs of formal and informal institutions, which served as the foundation for implementing strategies to encourage local scientific and technological activity. The case studies presented in this paper are too brief and preliminary, and we suspect most readers find the case study material wanting for additional 
details on the institutional transformations described for Taiwan and South Korea. Such details are necessary for constructing a convincing 'whole' of the stories of success and failure in economic development. The challenge lies in conducting these detailed case studies without losing sight of the full picture, even when the full picture complicates a modelled reality. 


\section{References}

Abramovitz M. (1989), Thinking about growth and other essays on economic growth and welfare Cambridge, Cambridge University Press.

Abramovitz, M. (1993). "The search for the sources of growth: Areas of ingnorance, old and new". Journal of Economic Review, 53(2):217-243.

Aghion P. and Howitt P. (1992), "A Model of Growth through Creative Destruction” Econometrica 60(2): 322-352.

Aghion P. and Howitt P. (1994), Endogenous Technical Change: The Schumpeterian Perspective, in L. Pasinetti and R. M. Solow (eds.), Economic Growth and the Structure of Long-Term Development. Proceedings of the IEA Conference, Varenna, Italy, vol. IEA Conference 112, St. Martin's Press, pp 118-131

Amable B. and Guellec D. (1992), "Les Théories de la Croissance Endogène" Revue d'Economie Politique 102(3): 313-377.

Amsden, A.H. (2001). The Rise of "the Rest": Challenges to the West from Late-industrializing Economies. (Oxford: Oxford University Press).

Andersen E. S. (1999), "Multisectoral Growth and national innovations systems" Nordic Journal of Political Economy 25(1): 33-52.

Andersen, E.S. and Lundvall, B.-A. (1988), "Small National Systems of Innovation Facing the Technological Revolution," in: Freeman and Lundvall (eds) Small Countries Facing the Technological Revolution, Pinter, London.

Andersen, E.S., Teubal, M. (1999), "The transformation of innovation systems: Towards a policy perspective" Paper presented at the DRUID Conference Rebild, Denmark.

Arocena R. and Sutz J. (2000). "Interactive Learning Spaces and Development Policies in Latin America," DRUID Working Paper No. 00-13.

Arocena, R. and Sutz, J. (2003): "Knowledge, Innovation and Learning: Systems and Policies in the North and in the South," in Cassiolato et al. (eds.), Systems of Innovation and Development, Edward Elgar Publishing, UK, pp. 291-310.

Arrow K. (1962). "The Economic Implications of Learning by Doing” Review of Economic Studies 29(2): $155-173$.

Barro R. (1990). "Government Spending in a Simple Model of Endogenous Growth” Journal of Political Economy 98(5-2): S71-S102.

Benabou, R. (1996). "Inequality and Growth," NBER Macroeconomics Annual.

Bijker, W.E. (1995), Of bicycles, bakelite and bulbs: Toward a Theory of Sociotechnical Change, MIT Press, Boston, MA.

Bourdieu, P. (1983). Forms of capital. In: Richards, J. C. ed. Handbook of theory and research for the sociology of education, New York, Greenwood Press.

Caracostas and Soete (1997). "The building of Cross-Border Institutions in Europe: Towards a European System of Innovation?" in Edquist. C. Systems of innovation: Technologies, globalisation and economic performance. (London: Pinter).

Chang, Ha-Joon. (2003). Globalization. Economic Development and the Role of the State. (London and New York: Zed Books Ltd.).

Chowdhury, A. and I. Islam (1993). The Newly Industrializing Economies of East Asia. (London and New York: Routledge).

Carlsson B. (2004). "Innovation Systems: A Survey of the Literature from a Schumpeterian Perspective, Paper presented at the International Schumpeter Society conference, Milan, June 912. 
Carlsson B. and Eliasson G. (2003). "Industrial Dynamics and Endogenous Growth" Industry and Innovation 10(4): 435-455.

Cassiolato et al. (2003). (eds) Systems of innovation and development. Cheltenham: Elgar.

Chiaromonte F. and Dosi G. (1993), "Heterogeneity, Competition, and Macroeconomic Dynamics" Structural Change and Economic Dynamics 4: 39-63.

Cimoli M. (1994), "Lock--in Specialization (Dis)Advantages in a Structuralist Growth Model" in Fagerberg J., Verspagen B. and von Tunzelmann N. (Eds.), The Dynamics of Technology Trade and Growth Aldershot, Edward Elgar

Cimoli M. and Soete L. (1992), “A Generalized Technological Gap Trade Model” Economie Appliquée 45(3): 33-54.

Coleman, J. C. 1988: Social capital in the creation of human capital. American Journal of Sociology 94: S95S120.

Constant, E.W. (1980), The origins of the turbojet revolution, Johns Hopkins University Press, Baltimore, MD.

Coombs R., Saviotti P. and Walsh V. (1987), Economics and technological change Basingstoke, Macmillan Education

Cooke, P. and K. Morgan (1998). The Associational Economy: Firms, Regions and Innovation. (Oxford: Oxford University Press).

Cooley, C.H. ([1902] 1956). Social Organization (Glencoe IL: Free Press)

Commons, J.R. (1924). The Legal Foundations of Capitalism (New York: Macmillan)

Conlisk, J. (1996). “Why Bounded Rationality?”, Journal of Economic Literature, 34: 669-700.

Coriat, B. and G. Dosi (1998). "The Institutional Embeddedness of Economic Change: An Appraisal of the 'Evolutionary' and 'Regulationist' Research Programmes" in Nielsen, K. and B. Johnson, Institutions and Economic Change: New Perspectives on Markets, Firms and Technology (Cheltenham, UK: Edward Elgar), pp. 3-32.

David, P.A. (1975). Technical Choice, Innovation and Economic Growth, Cambridge University Press, UK.

Davis, K. (1949). Human Society. (New York, NY: Macmillan).

de la Rive Box, L. (2001). "To and Fro: International Cooperation in Research and Research in International Cooperation". Inaugural lecture presented upon acceptance of the position of Professor in International Cooperation at the Faculty of Arts and Cultural Sciences, Maastricht University, October 12, 2001 (Maastricht: Maastricht University Press).

DiMaggio, P. and W. Powell (1983). "The Iron Cage Revisited: Institutional Isomorphism and Collective Rationality in Organizational Fields". American Sociological Review, 48:147-160.

Doloreux, D. and S. Parto. 2005. "Regional Innovation Systems: Current Discourse and Unresolved Issues," Technology in Society, 27:2, pp. 133-154.

Domar E. (1946), "Capital Expansion, Rate of growth, and Employment" Econometrica 14(April): 137147.

Dosi G. (1988), "Sources, Procedures and Microeconomic Effects of Innovation" Journal of Economic Literature 26: 1120-1171.

Dosi G., et al. (1994a), "The Dynamics of International Differentiation: A Multi-country Evolutionary Model" Industrial and Corporate Chance 3(1): 225-241.

Dosi G., Freeman C. and Fabiani S. (1994b), "The Process of Economic Development: Introducing Some Styilized Facts and Theories on Technologies, Firms and Institutions" Industrial and Corporate Chance 3(1): 1-45.

Durkheim, É. ([1901] 1950). The Rules of Sociological Method (Glencoe, IL: Free Press).

Edquist, C. (1997). "Systems of innovation approaches. Their emergence and characteristics", in Edquist. C. (ed.) Systems of innovation: Tecbnologies, globalisation and economic performance. (London: Pinter), pp. 1-35.

Easterly W. (2002), The Elusive Quest for Growth. Economists' Adventures and Misadventures in the Tropics (Cambridge, MA: MIT Press). 
Edquist, Charles and Björn Johnson. "Institutions and Organizations in Systems of Innovation", in Edquist, Charles. (ed.) Systems of Innovation - Technologies, Institutions and Organizations (London: Pinter Publishers/Cassell Academic).

Fagerberg J. (2000), “Technological Progress, Structural Change and Productivity Growth: A Comparataive Study" Structural Change and Economic Dynamics 11: 393-411.

Fagerberg J. and Verspagen B. (2002), "Technology-gaps, innovation--diffusion and transformation: An Evolutionary Interpretation” Research Policy 31: 1291-1304.

Freeman, C. (1987). Technology Policy and Economic Performance. Lessons from Japan. London/New York, SPRU/Pinter Publishers.

Galli, R. and Teubal, M. (1997), "Paradigmatic shifts in National innovation systems" in Systems of innovation. Edquist, C. ed. Pinter: London, 342-370.

Galor, O. and J. Zeira, 1993, "Income Distribution and Macroeconomics", Review of Economic Studies, 60, 35-52.

Glomm, G. and Ravikumar, B. (1992). "Public versus Private Investment in Human Capital Endogenous Growth and Income Inequality," Journal of Political Economy, 100(4), pp. 813-34.

Grossman G. and Helpman E. (1989a), "Product Development and International Trade" Journal of Political Economy 97: 1261-1283.

Grossman G. and Helpman E. (1989b), Quality Ladders and Product Cycles, NBER WP, 3201, National Bureau of Economic Research, Cambridge, MA, December

Hamilton, W. (1932). "Institution". In Seligman E. R. A. and A. Johnson, Encyclopaedia of Social Sciences, 8. (London, Routledge) pp. 84-89.

Harrod R. F. (1949), “An Essay in Dynamic Theory” Economic Journal 49(194): 14-33

Hassink, R. (1994)“South Korea: Economic Miracle by Policy Miracle?”, MERIT/Infonomics Research Memorandum 1994-023

Hirschman A. O. (1958), The Strategy of Economic Development New Haven, Yale University Press

Hughes, T.P. (1983), Networks of power: Electrification in western society 1880-1930, (Baltimore, MD: Johns Hopkins University Press).

Jacobs, J. 1961: The death and life of great American cities. (New York: Random Books).

Jessop, B. (2001). "Institutional re(turns) and the strategic-relational approach." Environment and Planning A 33:1213-1235.

Johnson (1988). "An Institutional Approach to the Small Country Problem," in Freeman, C. and Lundvall, B.-A. (eds.), Small Countries Facing the Technological Revolution, Pinter Publishers, London and New York.

Johnson, B. (1992), "Institutional learning," in Lundvall, B.-A.. (ed.), National Innovation Systems: Towards a Theory of Innovation and Interactive Learning, London, Pinter Publishers.

Johnson, B. Dalum, D. and Lundvall, B.-Å. (1992). "Public Policy in the Learning Society", in Lundvall, B.-A. (ed.), National Systems of Innovation- Towards a Theory of Innovation and Interactive Learning, (London: Pinter Publishers).

Johnson, B. and Lundvall, B.- $\AA$ (2003). "Promoting innovation systems as a response to the globalising learning economy," in: Cassiolato, J. E. et al. (eds) Systems of innovation and development: evidence from Brazil. Cheltenham: Elgar, 2003.

Jones, C.I. (1995). “R\&D-Based Models of Economic Growth,” Journal of Political Economy, 103(4), pp. $759-84$.

Kaldor, N. (1966), Causes of the Slow rate of Economic Growth in the United Kingdom Cambridge, Cambridge University Press

Kaldor, N. and Mirrlees, J. A. (1962), “A New Model of Economic Growth” Review of Economic Studies 29(3): 174-192.

Katz, J. (2004). "The Limits of the Prevailing Orthodoxy," Conference Paper for DRUID's Development Conference, June. 
Kemp, R., Smith, K., and Becher, G. (2000), "How should we study the relationship between environmental regulation and innovation?" Final report of project "Methodological Approaches to Regulation and Innovation Studies" for DGIII-IPTS research programme.

Kim, L. (1997). From Imitation to Innovation: The Dynamics of Korea's Technological Learning. (Boston, MA: Harvard Business School Press).

Kim, S.-R. and Tunzelmann, N. v. (1998), Aligning internal and external networks: Taiwan's specialization in IT, Working Paper, 17,SPRU Electronic Working Papers Series, Brighton, January, http://www.sussex.ac.uk/spru/.

Krätke, S. (1999). “A regulationist approach to regional studies." Environment and Planning A 31: 683-704.

Kuznets, (1966). Modern Economic Growth: Rate, Structure and Spread, Yale University Press, New Haven, CT.

Lachmann, L. (1970), The legacy of Max Weber, Heinemann, London.

Lastres, H. M. M., Cassiolato, J. E.; Maciel, M. L. (2003). "Systems of Innovation for Development in the Knowledge Era," in Cassiolato, J. E.; et al. (eds.) Systems of innovation and development: evidence from Brazil. Cheltenham: Elgar.

Lorentz, A. (2004), Sectoral Specialisation and Growth Rate Differences Among Integrated Economies, LEM Working Paper Series 06, Laboratory of Economics and Management Sant'Anna School of Advanced Studies, Pisa, March

Los, B. and Verspagen, B. (2003), The Evolution of Productivity Gaps and Specialisation Patterns, Working Paper, mimeo,University of Groningen, Groningen

Lucas, R. E. B. (1988), "On the Mechanisms of Economic Development" Journal of Monetary Economics 22: $3-42$

Lundvall, B.- $\AA$ (1988), "Innovation as an Interactive Process: From User-Producer Interactions to the National System of Innovation", in Dosi, G. et al. (eds.) Technical Change and Economic Theory, Pinter Publishers, London.

Lundvall, B.- $\AA$ (1992) (ed). National systems of innovation: Towards a theory of innovation and interactive learning, Pinter, London.

Lundvall, B.- $\AA$ et al. (2002). "National systems of production, innovation and competence building," Research Policy, vol. 31(2), pp. 213-231.

Mankiw, N.G., Romer, D. and Weil, D.N. (1992). "A Contribution to the Empirics of Economic Growth," NBER Working Papers 3541, National Bureau of Economic Research, Inc.

March, J.G. and J.P. Olsen (1984). "The New Institutionalism", American Political Science Review 78:734-749.

Metcalfe, J.S. (2000), “Co-evolution of systems of innovation,” Paper presented at the Volkswagen Foundation Conference "Perspectives and Challenges for Research and Innovation," Berlin, June 8-9.

Murmann, J.P. (2003).Knowledge and Competitive Advantage: The Coevolution of Firms, Technology, and National Institutions, Cambridge University Press, UK.

Myrdal G. (1957), Economic Theory and Under-developed Regions, London, Duckworth.

Nelson, R.R. (1988). "Institutions Supporting Technical Change in the United States", in Dosi, G. et al. (eds.) Technical Change and Economic Theory, Pinter Publishers, London.

Nelson, R.R.. (1994) "Economic growth via the coevolution of technology and institutions" in Evolutionary Economics and Chaos Theory, Leydesdorff and Besselar eds., 21-32.

Nelson, R.R. (1998). “The Co-Evolution of Technology, Industrial Structure, and Supporting Institutions." In Dosi, Giovanni, David Teece and Josef Chytry, eds., Technology, Organization, and Competitiveness. (New York: Oxford University Press).

Nelson, R.R. (2002). “Technology, Institutions, and Innovation Systems," Research Policy, vol. 31, pp. 265-272. 
Nelson, R.R. and Sampat, B.N. (2001), "Making Sense of Institutions as a Factor Shaping Economic Performance", Journal of Economic Behavior and Organization 44:31-54

Nelson, R.R. and S.G. Winter (1982), An evolutionary theory of economic change, (Cambridge, MA: Harvard Belknap Press).

Nelson, R.R. (1993), (ed) .National Innovation Systems: A Comparative Analysis. Oxford University Press: New York, pp. 3-21.

Nelson, R. R., Rosenberg, N. (1993), "Technical innovation and national systems" in Nelson, R. R. ed., pp. 3-21.

Niosi, J. (2002). "National Systems of Innovation are X-Efficient", Research Policy, 31 (2): pp. 291-302.

Niosi, J., Saviotti, P., Belon, B., Crow, W., 1993. Natural systems of innovators: In search of a workable concept. Technology in Society, vol. 15 (3), 207-227.

North, D.C. (1981). Structure and Change in Economic History, (New York: Norton).

Ostrom, E. (1999), "Institutional Rational Choice: An Assessment of the Institutional Analysis", in Sabatier, P.A. (ed.) Theories of the Policy Process (Boulder CO: Westview Press), pp. 35-73

Pack, H. (1994), "Endogenous Growth Theory: Intellectual Appeal and Empirical Shortcomings" Journal of Economic Perspectives 8(1): 55-72.

Parsons, T. ([1934] 1990). "Prolegomena to a Theory of Social Institutions" American Sociological Review 55: 319-39

Parto, S. (2005a). "Economic Activity and Institutions: Taking Stock", the Journal of Economic Issues $39(1): 31-52$.

Parto, S. (2005b). "'Good' Governance and Policy Analysis: What of Institutions?”, MERIT/Infonomics Research Memorandum 2005-001

Pasinetti, L. L. (1966), "Changes in the Rate of Profit and Switches of Techniques" Quarterly Journal of Economics 80: 503-517.

Pasinetti, L. L. (1981), Structural Change and Economic Growth. A Theoretical Essay on the Dynamics of the Wealth of Nations, Cambridge University Press, UK.

Pasinetti, L. L. (1994). "The Structure of Long Term Development: Concluding Remarks," in Pasinetti and R. M. Solow (eds.), Economic Growth and the Structure of Long-Term Development. Proceedings of the IEA Conference, Varenna, Italy, vol. 112, St. Martin's Press, pp 353-362.

Pavitt, K. (1984), "Sectoral Patterns of Technological Change: Towards a Taxonomy and Theory" Research Policy 13: 343-375.

Pavitt, K. and Patel, P. (1994). "Uneven (and divergent) technological accumulation among advanced countries: evidence and a framework of explanation," Industrial and Corporate Change 3: 759-87.

Persson, T. and Tabellini, G. (1994). "Is Inequality Harmful for Growth?" American Economic Review, 84(3), pp. 600-621.

Perotti, R. (1993). "Political Equilibrium, Income Distribution, and Growth," Review of Economic Studies, 60(4), pp. 755-76.

Petit, P. (1999). "Sectoral Patterns of Distribution in Slowly Growing Economies: the case of nine OECD countries in the 1980s and 1990s," International Review of Applied Economics, Taylor and Francis Journals, 13(3): 333-351.

Prebish R. (1950), The economic Development of Latin America and its Principal Problems New York, United Nations.

Putnam, R. D. (1993). Making democracy work. Civic traditions in modern Italy. Princeton NJ, Princeton University Press.

Putnam, R. D. (1995). Bowling alone: America's declining social capital. The Journal of Democracy 6(1): 65-78.

Putnam, R. D. (2000). Bowling alone. The collapse and revival of American community. New York, Simon and Schuster. 
Robinson J. (1953-54), "The Production Function and the Theory of Capital" Review of Economic Studies 21(2): 81-106.

Romer P. M. (1986), "Increasing Returns and Long Run Growth" Journal of Political Economy 94(5): 1002-1037.

Romer P. M. (1989), Capital Accumulation in the Theory of Long Run Growth. In: Barro R. (Ed.), Modern Business Cycle Theory Cambridge, MA, Harvard University Press: 51-127

Romer P. M. (1990), "Endogenous Technological Change" Journal of Political Economy 98(5, Part 2: The Problem of Development: A Conference of the Institute for the Study of Free Enterprise Systems): S71-S102.

Romer P. M. (1993), "Idea Gaps and Object Gaps in Economic Development" Journal of Monetary Economics 32(3): 543-573.

Romer P. M. (1994), “The Origins of Endogenous Growth" Journal of Economic Perspectives 8(1): 3-22

Saviotti P. P. and Pyka A. (2004), "Economic development by the creation of new sectors" Journal of Evolutionary Economics 14(1): 1-35.

Scott, W.R. (2001). Institutions and Organizations, $2^{\text {nd }}$ edition, (London: Sage Publications).

Silverberg G. and Verspagen B. (1994a), "Learning, Innovation and Economic Growth: A Long--Run Model of Industrial Dynamics" Industrial and Corporate Chance 3(1): 199-223.

Silverberg G. and Verspagen B. (1994b), "Collective Learning, Innovation and Growth in a Boundedly Rational, Evolutionary World” Journal of Evolutionary Economics 4: 207-226.

Silverberg, G. and B. Verspagen (1995). "Evolutionary theorizing on economic growth" IIASA WP95-78, Laxenburg, Austria.

Simon (1981). The sciences of the Artificial, MIT Press, MA.

Singer H. K. (1950), "The Distribution of Gains Between Investing and Borrowing Countries" American Economic Review 40: 473-485.

Smelser, N. and R. Swedberg (1994) (eds.), The Handbook of Economic Sociology (Princeton, NJ: Princeton University Press).

Solow, R.M. (1956), "A contribution to theory of economic growth," Quarterly Journal of Economics, 70, 65-94.

Solow, R. M. (1957), "Technical Change and the Aggregate Production Function" Review of Economics and Statistics 39: 312-320.

Solow R. M. (1994a), Concluding Comments, in L. Pasinetti and R. M. Solow (eds.), Economic Growth and the Structure of Long-Term Development. Proceedings of the IEA Conference, Varenna, Italy, vol. IEA Conference 112, St. Martin's Press, pp 376-379

Solow R. M. (1994), "Perspectives on Growth Theory" Journal of Economic Perspectives 8(1): 45-54.

Swan T. W. (1956), "Economic Growth and Capital Accumulation" Economic Record 32: 334-361.

Thirlwall A. P. (1979), "The Balance of Payments Constraint as an Explanation of International Growth Rate Differences" Banca Nazionale del Lavoro Quarterly Review XXXII: 45-53.

Veblen, T.B. (1919). The Place of Science in Modern Civilization and Other Essays (New York: Huebsch).

Verspagen B. (1993), Uneven Growth Between Interdependent Economies. The Evolutionary Dynamics of Growth and Technology Aldershot, Avebury

Verspagen B. (2002), "Evolutionary Macroeconomics: A Synthesis between neo--Schumpeterian and post--Keynesians Lines of Thought" Electronic Journal of Evolutionary Modeling and Economic Dynamics(1007).

von Tunzelmann, G.N. (1978), Steam power and British industrialization to 1860, Clarendon Press, Oxford. von Tunzelmann G.N. (1995), Technology and Industrial Progress: The Foundations of Economic Growth, Aldershot, Edward Elgar

Vogel, E.F. (1991). The Four Little Dragons: The Spread of Industrialization in East Asia. (Cambridge, MA: Harvard University Press).

Wade, R. (1990), Governing the Market: Economic Theory and the Role of Government in East Asian Industrialization (Princeton, NJ: Princeton University Press). 
Weber, M. (1924), "Class, Status and Party", in Gerth, H., and C.W. Mills (1948), Essays from Max Weber (London: Routledge and Kegan Paul).

Winner, L. (1986), The Whale and the Reactor: A Search for Limits in an Age of High Technology, University of Chicago Press.

Wood A. (1994), Comment on "Part I: Empirical Evidence", in L. Pasinetti and R. M. Solow (eds.), Economic Growth and the Structure of Long-Term Development. Proceedings of the IE A Conference, Varenna, Italy, vol. IEA Conference 112, St. Martin's Press, pp 65-70.

World Bank (1993). "The East Asian Miracle: Economic Growth and Public Policy (A World Bank Policy Research Report). (New York: Oxford University Press).

Young, O. R. (1994). International Governance: Protecting the Environment in a Stateless Society. (Ithaca: Cornell University Press)

Young, O. R. (2002). The Institutional Dimensions of Environmental Change: Fit, Interplay, and Scale (Cambridge: The MIT Press)

Zysman, J. (1994), "How institutions create historically rooted trajectories of growth," Industrial and Corporate Change 3(1), 243-28 